\title{
Systematic Review \\ Immune-Checkpoint Inhibitors for Metastatic Colorectal Cancer: A Systematic Review of Clinical Outcomes
}

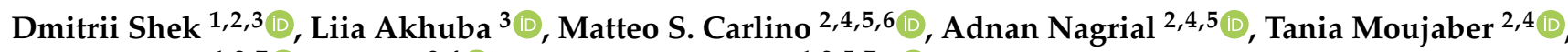 \\ Scott A. Read 1,2,7 (D) Bo Gao ${ }^{2,4}$ (D) and Golo Ahlenstiel 1,2,5,7,*(D) \\ 1 Blacktown Clinical School, Western Sydney University, Sydney, NSW 2148, Australia; \\ Dmitri.Shek@health.nsw.gov.au (D.S.); S.Read@westernsydney.edu.au (S.A.R.) \\ 2 Blacktown Hospital, Sydney, NSW 2148, Australia; Matteo.Carlino@health.nsw.gov.au (M.S.C.); \\ Adnan.Nagrial@health.nsw.gov.au (A.N.); Tania.Moujaber@health.nsw.gov.au (T.M.); \\ Bo.Gao@health.nsw.gov.au (B.G.) \\ 3 Accreditation Centre, RUDN University, 117198 Moscow, Russia; Akhuba_lg@rudn.university \\ 4 Crown Princess Mary Cancer Centre, Westmead Hospital, Sydney, NSW 2145, Australia \\ 5 Westmead Clinical School, The University of Sydney, Sydney, NSW 2145, Australia \\ 6 Melanoma Institute Australia, Sydney, NSW 2065, Australia \\ 7 Storr Liver Centre, Westmead Institute for Medical Research, Sydney, NSW 2145, Australia \\ * Correspondence: Golo.Ahlenstiel@health.nsw.gov.au; Tel.: +61-2-9851-6073; Fax: +61-2-9851-6050
}

\section{check for} updates

Citation: Shek, D.; Akhuba, L.; Carlino, M.S.; Nagrial, A.; Moujaber, T.; Read, S.A.; Gao, B.; Ahlenstiel, G. Immune-Checkpoint Inhibitors for Metastatic Colorectal Cancer: A Systematic Review of Clinical Outcomes. Cancers 2021, 13, 4345. https://doi.org/10.3390/ cancers 13174345

Academic Editors: Lisa Salvatore and Arndt Vogel

Received: 30 July 2021

Accepted: 25 August 2021

Published: 27 August 2021

Publisher's Note: MDPI stays neutral with regard to jurisdictional claims in published maps and institutional affiliations.

Copyright: (c) 2021 by the authors. Licensee MDPI, Basel, Switzerland. This article is an open access article distributed under the terms and conditions of the Creative Commons Attribution (CC BY) license (https:/ / creativecommons.org/licenses/by/ $4.0 /)$.
Simple Summary: In 2018, colorectal cancer (CRC) was declared the fourth most deadly cancer worldwide. Unfortunately, a quarter of all patients are diagnosed at late stages, when curative surgery is not possible, rendering systemic therapy and/or best supportive care as the only options. To our knowledge, this is the first systematic review assessing response and survival rates in patients with mCRC treated with immune-checkpoint inhibitors (ICIs). Our study established that ICIs show potentially superior response rates in $\mathrm{mCRC}$ patients, though only in those with high microsatellite instability (MSI). Nivolumab + regorafenib was reported to provide encouraging response in low-MSI (MSI-L) patients; however, additional studies using cohort randomization are required. Further studies are required, particularly regarding the mechanism of resistance to ICIs in MSI-L patients.

Abstract: Background. Colorectal cancer (CRC) is the fourth most deadly cancer worldwide. Unfortunately, a quarter of the patients are diagnosed at late stages, when surgical options are limited. Targeted therapies, particularly immune-checkpoint inhibitors (ICIs), are the latest addition and have been studied herein regarding their efficacy outcomes. Methods. Clinical studies were identified through the PubMed, Scopus and Cochrane databases. Any trial that evaluated ICIs in patients with metastatic CRC (mCRC) and reported the objective response rate was deemed eligible. Data analysis was performed by employing the random-effects model in STATA v.17. Results. A total of 461 articles were identified; 13 clinical trials were included, encompassing a total cohort of 1209 patients. Our study determined that a single PD-1/PD-L1 checkpoint blockade provides durable clinical response in $\mathrm{mCRC}$ patients with high microsatellite instability (MSI-H). The combinatorial therapy of CTLA-4 + PD-1 inhibitors also showed high response rates in pre-treated MSI-H patients. The single-arm REGONIVO trial reported durable clinical response in patients with microsatellite stable (MSS) status. Conclusions. Our study surmises that PD-1/PD-L1 inhibitors as well as combination therapy with CTLA-4 and PD-1 inhibitors show encouraging response rates in mCRC patients, albeit exclusively in patients with cancer that are of MSI-H status. A single study suggest that nivolumab + regorafenib can reach a durable response rate in MSS patients; however, further studies in larger randomized settings are required.

Keywords: colorectal cancer; pembrolizumab; atezolizumab; nivolumab; ipilimumab; targeted therapy; immune-checkpoint inhibitors 


\section{Introduction}

Colorectal cancer (CRC) is the fourth most common cause of cancer-related mortality, accounting for $10 \%$ of all annually diagnosed malignancies worldwide [1]. It is the second most common cancer in women and the third most common in men [2], with the yearly incidence to surpass 2.5 million by 2035 [3]. Despite the availability of screening programs, $25 \%$ of all new CRC cases are still diagnosed at advanced stages [4,5] (Figure 1). For decades, chemotherapy has been the primary treatment for metastatic CRC [6], particularly fluorouracil (5-FU /F), oxaliplatin (OX), irinotecan (IRI) and capecitabine (CAP), alone or in combination [7]. Unfortunately, high risk of systemic toxicity, poor response rates and low efficacy have driven the search for better treatment options with higher tumor-specific selectivity, especially among patients with late-stage disease progression [7].

\begin{tabular}{|c|c|c|c|c|}
\hline AJCC stage & Stage 0-I & Stage II & Stage III & Stage IV \\
\hline & \multirow[t]{2}{*}{$\begin{array}{l}\text { Stage } 0 \\
\text { Tis (intramucosal } \\
\text { carcinoma) }\end{array}$} & \begin{tabular}{|lll}
$\mathrm{IIA}$ & $\mathrm{IIC}$ \\
\end{tabular} & \begin{tabular}{|llll}
$\mathrm{IIIA}$ & $\mathrm{III} \mathrm{B}$ \\
\end{tabular} & \begin{tabular}{|l|l|l|l|} 
IV A & IV \\
\end{tabular} \\
\hline & & All stages are NO, MO & All stages are M0 & Any $\mathrm{T}$, Any $\mathbf{N}$ \\
\hline \multirow{4}{*}{ Muscle la } & \multirow{5}{*}{$\begin{array}{l}\text { T1 spread to } \\
\text { submucosa } \\
\text { OR } \\
\text { T2 spread to } \\
\text { muscle layers } \\
\text { N0 no spread to } \\
\text { lymph nodes } \\
\text { M0 no distant } \\
\text { metastases }\end{array}$} & T3 spread to serosa & \multirow{2}{*}{$\begin{array}{l}\text { T1/T2; N1 spread into 1-3 nearby lymph } \\
\text { nodes / N1C spread into fat near lymph } \\
\text { nodes but not the nodes themselves } O R \\
\text { T1; N2a spread into 4-6 nearby lymph } \\
\text { nodes }\end{array}$} & $\begin{array}{l}\text { M1 a spread into one } \\
\text { distant organ } O R \text { one } \\
\text { distant set of lymph nodes }\end{array}$ \\
\hline & & $\begin{array}{l}\text { T4a spread through } \\
\text { all layers but not grown } \\
\text { into nearby tissues }\end{array}$ & & $\begin{array}{l}\text { M1b spread into }>1 \\
\text { distant organ } O R>1 \text { distant } \\
\text { set of lymph nodes }\end{array}$ \\
\hline & & $\begin{array}{l}\text { T4b spread through } \\
\text { all layers and attached } \\
\text { or has grown into } \\
\text { nearby tissues }\end{array}$ & $\begin{array}{l}\text { T3/T4a; N1/N1c oR } \\
\text { T2/T3; N2a oR } \\
\text { T1/T2; N2b spread into >7 nearby } \\
\text { lymph nodes }\end{array}$ & \multirow{2}{*}{$\begin{array}{l}\text { M1c spread into distant } \\
\text { parts of peritoneum (the } \\
\text { lining of the abdominal } \\
\text { cavity) and may or may } \\
\text { not into distant organs, } \\
\text { lymph nodes }\end{array}$} \\
\hline & & & $\begin{array}{l}\text { T4a; N2a OR } \\
\text { T3/T4a; N2b oR }\end{array}$ & \\
\hline \multirow{2}{*}{$\begin{array}{l}\text { Relative survival rate: } \\
1 \text { Year; } 3 \text { Years; } \\
5 \text { Years * }\end{array}$} & & & T4b; N1/N2 & \multirow[b]{2}{*}{$49.3 \% ; 22.8 \% ; 13.4 \%$} \\
\hline & $\begin{array}{l}98.8 \% \\
98.6 \%\end{array}$ & $96.4 \% ; 92.9 \% ; 88.6 \%$ & $93.5 \% ; 79.1 \% ; 71.3 \%$ & \\
\hline
\end{tabular}

Figure 1. Colorectal cancer stages according to the American Joint Committee on Cancer (AJCC), 8th edition [8]. TNM staging is based on the size of the tumor, growth into lymph nodes and distant metastases to organs and/or tissues. Relative survival rate is an epidemiological characteristic comparing people with the specific histological type and stage of cancer to the overall population in a specific area/region of our country. 1-,3- and 5-year relative survival rates reduce drastically as CRC progresses from stage 0 to 4 .

Targeted therapies provide an alternative for patients with metastatic CRC. Targeted therapies function by blocking specific molecules involved in cancer growth and dissemination [9]. In CRC, several potential targets have been studied over the past 20 years (Figure 2), including epidermal growth factor receptor (EGFR) inhibition [10] as well as suppression of the Ras-Raf-MEK-ERK pathway, which is responsible for cell growth, proliferation and survival [11,12]. Vascular endothelial growth factor-A (VEGF-A), which promotes tumor angiogenesis [13-15], is another critical target. The first anti-VEGF-A mAb, bevacizumab, was approved in 2004 [16]. Since then, the Food and Drug Administration (FDA) has granted approval to aflibercept (inhibitor of VEGF-A), ramucirumab (fully humanized $\mathrm{mAb}$ against VEGFR-2) and regorafenib (inhibitor of VEGFR-2) for the treatment of CRC [16]. However, treatment resistance is inevitable and novel treatment options are needed. 


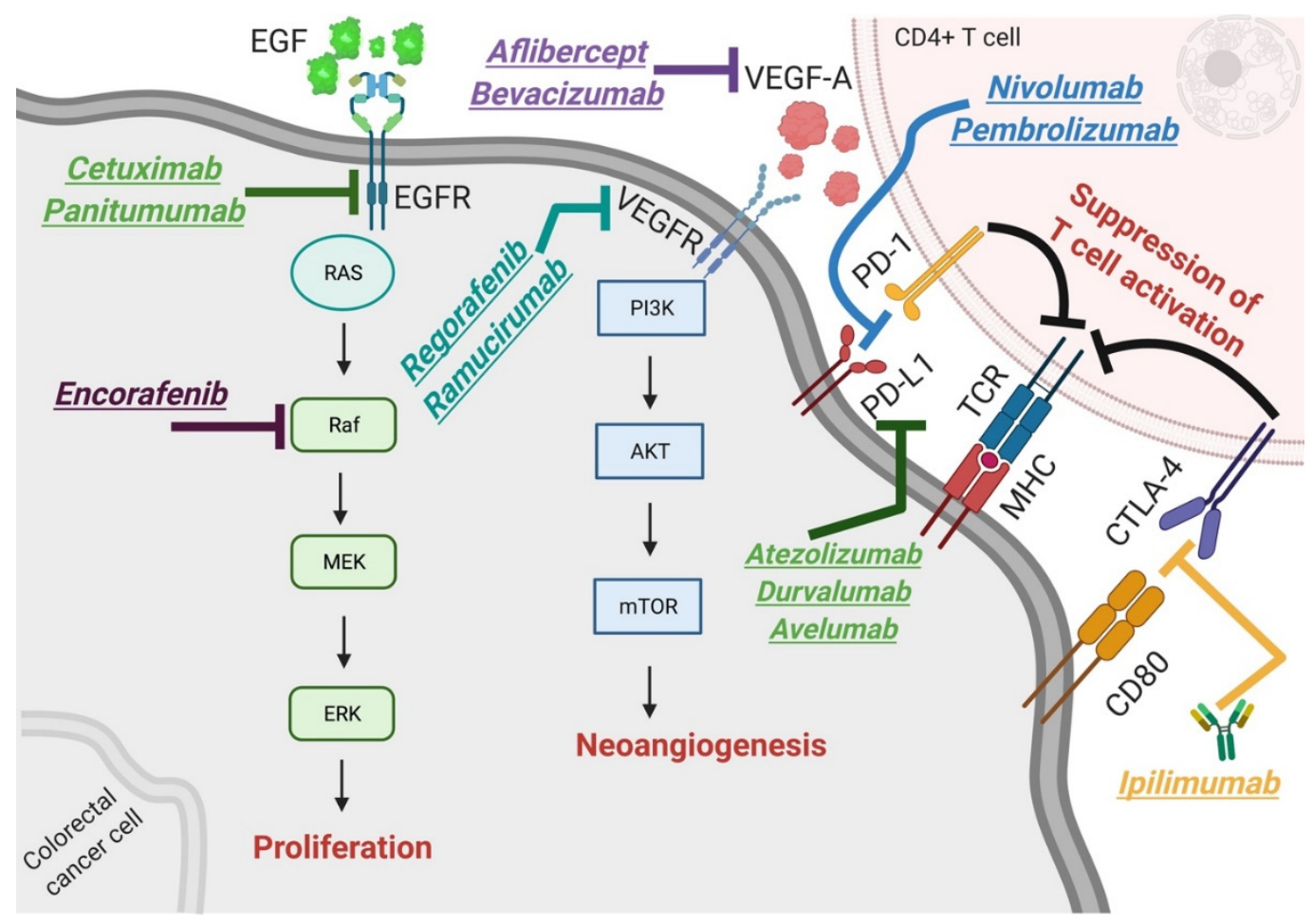

Figure 2. Molecular mechanisms of targeted drugs approved by the Food and Drug Administration for the treatment of metastatic colorectal cancer. (1) Anti-EGFR (epidermal growth factor receptor) monoclonal antibodies (mAbs) cetuximab and panitumumab; (2) encorafenib, an inhibitor of the Raf protein as part of the MAPK/ERK signaling pathway; (3) VEGF-A (vascular endothelial growth factor-A) inhibitors aflibercept and bevacizumab; (4) VEGF receptor inhibitors regorafenib and ramucirumab; (5) anti-PD-1 (programmed cell death-1) mAbs nivolumab and pembrolizumab and anti-PD-L1 (programmed cell death ligand 1) mAbs atezolizumab, durvalumab and avelumab; (6) anti-CTLA-4 (cytotoxic T lymphocyte-associated antigen-4) mAb ipilimumab. Current targeted therapies inhibit three major processes crucial for cancer growth: unrestricted proliferation, neo-angiogenesis and suppression of $\mathrm{T}$ cell immune responses.

A recent therapeutic addition to the $\mathrm{CRC}$ treatment regimen are immune-checkpoint inhibitors (ICIs) [17]. ICIs are mAbs targeting inhibitors of T cell receptor (TCR) activation, particularly programmed cell death-1 (PD-1), programmed cell death ligand 1 (PD-L1) and cytotoxic T lymphocyte-associated antigen-4 (CTLA-4) expressed in T cells and antigenpresenting cells [17]. They have become widely used in many cancers, including melanoma, RCC, NSCLC and HCC [18]. In mCRC, this treatment modality has already shown an encouraging clinical response [19] in patients with high microsatellite instability (MSI-H) in mismatch repair (MMR) genes such as MutL homolog 1 (MLH1), MutS homolog 2, 6 (MSH2, MSH6), PMS2 and tumor-associated calcium signal transducer 1/epithelial cell adhesion molecule (TACSTD1/EPCAM) [20]. However, MSI-H CRC accounts for $5 \%$ of the total cases, with the remaining $95 \%$ of CRC cancers classified as microsatellite stable (MSS) or low microsatellite instability (MSI-L) [20], where the efficacy of ICIs is yet to be defined. This study aims to comprehensively summarize existing knowledge regarding response and survival rates and outline major barriers to ICI treatment in patients with mCRC.

\section{Methods}

\subsection{Eligibility Criteria and Data Collection}

For the purpose of this study, we utilized the following eligibility criteria: (1) patients with mCRC; (2) PD-1, PD-L1, CTLA-4 inhibitors used for treatment either as a single agent or in combination with chemotherapeutic/biological agents; (3) ORR was reported; (4) published in English. Systematic reviews and meta-analysis, case reports, studies with no ORR data and studies not published in the English language were excluded. 
The following data were obtained from studies deemed eligible: (1) NCT, trial phase; (2) number of patients; (3) treatment regimen(s); (4) number of previous lines of treatments; (5) ORR with 95\% CI; (6) median PFS with 95\% CI; (7) microsatellite instability (MSI) status (Table 1).

Table 1. List of studies included in this systematic review. ICI-immune-checkpoint inhibitor; NIVO-nivolumab; IPI—ipilimumab; PEMBRO—pembrolizumab; ATEZO—atezolizumab; DURVA—durvalumab; TREM—tremelimumab; Q3W—every 3 weeks; CI—confidence interval; PFS—progression-free survival; ORR—objective response rate; PD-L1— programmed cell death-1 ligand 1; mo-months; MSI-H—microsatellite instability-high; MSS—microsatellite stable; $\mathrm{d} / \mathrm{pMMR}$ — deficient/proficient mismatch repair gene; wt—wild type; $\mathrm{mt}$-mutated type.

\begin{tabular}{|c|c|c|c|c|c|c|c|}
\hline NCT & Phase & ICI & Total N & $\begin{array}{l}\text { Prior Systemic } \\
\text { Treatment: \% (n) }\end{array}$ & $\begin{array}{l}\text { Median PFS } \\
\text { (95\% CI })\end{array}$ & ORR (95\% CI) & Marker Status: \% (n) \\
\hline $\begin{array}{c}\text { NCT02060188 } \\
{[21]}\end{array}$ & 2 & $\begin{array}{c}\text { NIVO } 3 \mathrm{mg} / \mathrm{kg}+ \\
\text { IPI } 1 \mathrm{mg} / \mathrm{kg} \\
\text { Q3W (4 doses) } \\
\text { followed by } \\
\text { NIVO } 3 \mathrm{mg} / \mathrm{kg} \\
\text { Q2W }\end{array}$ & 119 & $\begin{array}{c}0: 1(1) \\
1: 23(27) \\
2: 36(43) \\
\geq 3: 40(48)\end{array}$ & NR & $\begin{array}{c}54.6 \% \\
(45.2 \text { to } 63.8)\end{array}$ & $\begin{array}{c}\text { BRAF/KRAS wt: } 26(31) \\
\text { BRAF mt: } 24(29) \\
\text { KRAS mt: } 37(44) \\
\text { PD-L1 } \geq 1 \%: 22(26) \\
\text { PD-L1 < 1\%: } 55(65) \\
\text { Unknown: } 24(28)\end{array}$ \\
\hline $\begin{array}{c}\text { NCT02460198- } \\
\text { cohort A } \\
\text { [22] }\end{array}$ & 2 & $\begin{array}{l}\text { PEMBRO } 200 \mathrm{mg} \\
\text { Q3W }\end{array}$ & 61 & $\begin{array}{c}\text { 1: } 10(6) \\
\text { 2: } 46(28) \\
\geq 3: 44(27)\end{array}$ & $\begin{array}{c}2.3 \text { mo. } \\
(2.1 \text { to } 8.1)\end{array}$ & $33 \%(21$ to 46$)$ & $\begin{array}{c}\text { MSI-H/dMMR: } 100(61) \\
\text { BRAF/KRAS/NRAS wt: } \\
18(11) \\
\text { BRAF mt: } 15(9) \\
\text { KRAS mt: } 26(16) \\
\text { NRAS mt: } 5 \text { (3) }\end{array}$ \\
\hline $\begin{array}{c}\text { NCT02460198- } \\
\text { cohort B } \\
\text { [22] }\end{array}$ & 2 & $\begin{array}{l}\text { PEMBRO } 200 \mathrm{mg} \\
\text { Q3W }\end{array}$ & 63 & $\begin{array}{c}\text { 1: } 38(24) \\
2: 32(20) \\
\geq 3: 30(19)\end{array}$ & $\begin{array}{l}4.1 \mathrm{mo} . \\
(2.1 \text { to } 18.9)\end{array}$ & $33 \%(22$ to 46$)$ & $\begin{array}{c}\text { MSI-H/dMMR: } 100(63) \\
\text { BRAF/KRAS/NRAS wt: } \\
9(6) \\
\text { BRAF mt: } 8(5) \\
\text { KRAS mt: } 35(22) \\
\text { NRAS mt: } 8 \text { (5) }\end{array}$ \\
\hline $\begin{array}{c}\text { NCT02060188 } \\
{[23]}\end{array}$ & 2 & $\begin{array}{c}\text { NIVO } 3 \mathrm{mg} / \mathrm{kg} \\
\text { Q3W }\end{array}$ & 74 & $\begin{array}{c}0: 1(1) \\
\text { 1: } 15(11) \\
\text { 2: } 30(22) \\
\geq 3: 54(40)\end{array}$ & $\begin{array}{l}14.3 \mathrm{mo} . \\
\text { (4.3 to NR) }\end{array}$ & $\begin{array}{c}31.1 \% \\
(20.8 \text { to } 42.9)\end{array}$ & $\begin{array}{c}\text { MSI-H/dMMR: } 100(74) \\
\text { BRAF/KRAS wt: } 39(29) \\
\text { BRAF mt: } 16(12) \\
\text { KRAS mt: } 35(26) \\
\text { Unknown: } 9(7) \\
\text { PD-L1 } \geq 1 \%: 28(21) \\
\text { PD-L1<1\%: } 64(47) \\
\text { Unknown: } 8(6)\end{array}$ \\
\hline $\begin{array}{c}\text { NCT01633970 } \\
{[24]}\end{array}$ & $1 b$ & $\begin{array}{c}\text { ATEZO } 1200 \mathrm{mg} \\
\text { Q3W + } \\
\text { Bevacizumab }\end{array}$ & 10 & $\begin{array}{c}\text { 1: } 30(3) \\
\geq 2: 70(7)\end{array}$ & NR & $\begin{array}{c}30 \% \\
(6.7 \text { to } 65.3)\end{array}$ & $\begin{array}{l}\text { MSI-H/dMMR: } 100 \\
(10)\end{array}$ \\
\hline $\begin{array}{c}\text { NCT01693562 } \\
{[25]}\end{array}$ & $1 / 2$ & $\begin{array}{c}\text { DURVA } 10 \\
\mathrm{mg} / \mathrm{kg} \text { Q2W }\end{array}$ & 36 & - & 6 mo. (3 to 20$)$ & $22 \%$ (10 to 39$)$ & $\begin{array}{l}\text { MSI-H/dMMR: } 100 \\
(36)\end{array}$ \\
\hline $\begin{array}{c}\text { NCT02873195 } \\
{[26]}\end{array}$ & 2 & $\begin{array}{c}\text { Capecitabine + } \\
\text { ATEZO } 1200 \text { mg } \\
\text { Q3W + } \\
\text { Bevacizumab }\end{array}$ & 82 & - & $\begin{array}{c}4.4 \mathrm{mo} . \\
(4.1 \text { to } 6.4)\end{array}$ & $\begin{array}{c}8.54 \% \\
(3.5 \text { to } 16.8)\end{array}$ & MSS/pMMR: 85.7 (70) \\
\hline $\begin{array}{c}\text { NCT03406871 } \\
\text { [27] }\end{array}$ & $1 b$ & $\begin{array}{c}\text { NIVO } 3 \mathrm{mg} / \mathrm{kg} \\
\text { Q2W }+ \\
\text { Regorafenib }\end{array}$ & 25 & - & $\begin{array}{c}7.9 \text { mo. } \\
\text { (2.9 to NR) }\end{array}$ & $36 \%$ (18 to 57.5$)$ & $\begin{array}{l}\text { MSI-H/dMMR: } 0(0) \\
\text { MSS/pMMR: } 100(25) \\
\text { PD-L1 } \geq 1 \%: 42(10) \\
\text { PD-L1 < 1\%: } 58(14)\end{array}$ \\
\hline $\begin{array}{c}\text { NCT01988896 } \\
\text { [28] }\end{array}$ & $1 / 1 b$ & $\begin{array}{c}\text { ATEZO } 800 \text { mg } \\
\text { Q2W + } \\
\text { cobimetinib }\end{array}$ & 84 & - & $\begin{array}{c}1.9 \text { mo. } \\
(1.8 \text { to } 2.3)\end{array}$ & $8 \%(3$ to 16$)$ & $\begin{array}{c}\text { MSI-H/dMMR: } 2.4(2) \\
\text { MSS/pMMR: } 72(60) \\
\text { MSI-Unknown: } 21(18) \\
\text { BRAF mt: } 6(5) \\
\text { KRAS mt: } 68(57) \\
\text { Unknown: } 23(19)\end{array}$ \\
\hline $\begin{array}{c}\text { NCT03150706 } \\
\text { [29] }\end{array}$ & 2 & $\begin{array}{c}\text { Avelumab } \\
10 \mathrm{mg} / \mathrm{kg} \mathrm{Q2W}\end{array}$ & 33 & $\begin{array}{l}\text { 1: } 48.5(16) \\
2: 33.3(11) \\
\geq 3: 18.2(6)\end{array}$ & $\begin{array}{c}3.9 \text { mo. } \\
(2.3 \text { to } 5.6)\end{array}$ & $\begin{array}{c}24.2 \% \\
(9.4 \text { to } 38.6)\end{array}$ & $\begin{array}{c}\text { BRAF mt: } 12.1(4) \\
\text { KRAS mt: } 60.6(20) \\
\text { Unknown: } 27(9)\end{array}$ \\
\hline
\end{tabular}


Table 1. Cont.

\begin{tabular}{|c|c|c|c|c|c|c|c|}
\hline NCT & Phase & ICI & Total N & $\begin{array}{l}\text { Prior Systemic } \\
\text { Treatment: \% (n) }\end{array}$ & $\begin{array}{c}\text { Median PFS } \\
(95 \% \mathrm{CI})\end{array}$ & ORR (95\% CI) & Marker Status: \% (n) \\
\hline $\begin{array}{c}\text { NCT02563002 } \\
\text { [19] }\end{array}$ & 3 & $\begin{array}{c}\text { PEMBRO } 200 \mathrm{mg} \\
\text { Q3W }\end{array}$ & 153 & $\begin{array}{l}0: 75(115) \\
>1: 25(38)\end{array}$ & $\begin{array}{c}16.5 \text { mo. } \\
(5.4 \text { to } 32.4)\end{array}$ & $\begin{array}{c}43.8 \% \\
(35.8 \text { to } 52)\end{array}$ & $\begin{array}{c}\text { MSI-H/dMMR: } 100 \\
\text { (153) } \\
\text { BRAF/KRAS wt: } 22(34) \\
\text { BRAF mt: } 22(34) \\
\text { KRAS mt: } 22(34) \\
\text { Unknown: } 34(52)\end{array}$ \\
\hline $\begin{array}{c}\text { NCT02788279- } \\
\text { cohort A } \\
{[30]}\end{array}$ & 3 & $\begin{array}{c}\text { ATEZO } 840 \text { mg } \\
\text { Q2W + } \\
\text { cobimetinib }\end{array}$ & 183 & $\begin{array}{l}<3: 73(134) \\
>3: 27(49)\end{array}$ & $\begin{array}{l}1.91 \text { mo. } \\
\text { (1.87 to } 1.97)\end{array}$ & $3 \%(0.9$ to 6.3$)$ & $\begin{array}{c}\text { MSI-H/dMMR: } 2(3) \\
\text { MSS/pMMR: } 93(170) \\
\text { BRAF wt: } 95(174) \\
\text { KRAS wt: } 46(84) \\
\text { BRAF mt: } 5(9) \\
\text { KRAS mt: } 54(99) \\
\\
\text { PD-L1 } \geq 1 \%: 43(79) \\
\text { PD-L1 < 1\%: } 46(84) \\
\text { Unknown: } 11(20)\end{array}$ \\
\hline $\begin{array}{c}\text { NCT02788279- } \\
\text { cohort B } \\
\text { [30] }\end{array}$ & 3 & $\begin{array}{c}\text { ATEZO } 1200 \mathrm{mg} \\
\text { Q3W }\end{array}$ & 90 & $\begin{array}{l}<3: 71(64) \\
>3: 29(26)\end{array}$ & $\begin{array}{c}1.94 \text { mo. } \\
\text { (1.91 to } 2.1)\end{array}$ & $2 \%(0.3$ to 7.8$)$ & $\begin{array}{l}\text { MSI-H/dMMR: } 3(3) \\
\text { MSS/pMMR: } 92(83) \\
\text { BRAF wt: } 97(87) \\
\text { KRAS wt: } 46(41) \\
\text { BRAF mt: } 3(3) \\
\text { KRAS mt: } 54(49) \\
\\
\text { PD-L1 } \geq 1 \%: 39(35) \\
\text { PD-L1 < } 1 \%: 47(42) \\
\text { Unknown: } 14(13)\end{array}$ \\
\hline $\begin{array}{l}\text { CAVE trial } \\
\text { [31] }\end{array}$ & 2 & $\begin{array}{l}\text { Avelumab } 10 \\
\text { mg/kg Q2W + } \\
\text { Cetuximab }\end{array}$ & 77 & 1: $100(77)$ & $\begin{array}{c}3.6 \mathrm{mo} . \\
(3.3 \text { to } 3.9)\end{array}$ & $6.1 \%(4.2$ to 9.8$)$ & KRAS wt: 100 (77) \\
\hline $\begin{array}{c}\text { NCT02870920 } \\
\text { [32] }\end{array}$ & 2 & $\begin{array}{c}\text { DURVA } 1500 \mathrm{mg} \\
\text { Q4W + TREM } \\
75 \mathrm{mgQ} 4 \mathrm{~W}\end{array}$ & 119 & - & $\begin{array}{c}1.8 \mathrm{mo} . \\
(1.8 \text { to } 1.9)\end{array}$ & $0.8 \%(0.2$ to 1.6$)$ & $\begin{array}{c}\text { MSI-H/dMMR: } 1(1) \\
\text { MSS/pMMR: } 98 \text { (117) } \\
\text { BRAF wt: } 92(110) \\
\text { KRAS wt: } 21(25) \\
\text { BRAF mt: } 7(8) \\
\text { KRAS mt: } 78(93)\end{array}$ \\
\hline
\end{tabular}

\subsection{Study Endpoints}

The primary endpoint is to systematically determine the ORR (according to Response Evaluation Criteria in Solid Tumors version 1.1 [RECIST v1.1]) in patients with mCRC treated with ICI-based therapies. In addition, we summarized median progression-free survival (PFS) with 95\% confidence interval (CI), if reported across selected studies.

\subsection{Literature Search and Study Endpoints}

This systematic review is reported in accordance with PRISMA (Preferred Reporting Items for Systematic Reviews and Meta-Analyses) reporting guidelines and is registered at the PROSPERO database (CRD42020197617) [33].

Three authors (D.S., L.A. and G.A.) independently conducted a comprehensive literature review through the electronic databases Scopus, MEDLINE, Web of Science and Cochrane Library from 30 September 2004 to 30 April 2021 using keywords (immunecheckpoint inhibitors, metastatic colorectal cancer, colon cancer, rectal cancer, targeted therapy, monoclonal antibodies, pembrolizumab, nivolumab, ipilimumab, atezolizumab) linked by operators "AND" and "OR." Abstracts presented at annual meetings of the American Society of Clinical Oncology (ASCO) and the European Society for Medical Oncology (ESMO) were also examined. Abstracts were considered eligible if the study was published for the first time and matched eligibility criteria. Finally, we searched through bibliographies of selected articles as well as clinical trial registries (www.clinicaltrials.gov (accessed from 1 May 2021 to 25 May 2021) using the aforementioned keywords.

The records found through primary search were initially screened by title and abstract. The full text of potentially eligible studies was reviewed, and if eligible the study was 
included in the analysis. Selected studies were reviewed by all authors and all discrepancies were solved by consensus. If one study was reported multiple times, the study with the most comprehensive and up to date data was included.

\subsection{Data Analysis}

Risk of bias in randomized studies was assessed using a revised Cochrane tool to assess risk of bias in randomized trials [34,35] whereas single-arm studies were assessed by the Newcastle-Ottawa tool for Cohort Studies [36]. PFS is defined as time (in months) from randomization to recurrence [37]. Study heterogeneity was calculated with $I^{2}$. $I^{2}$ values less than $25 \%, 50 \%$ and $75 \%$ were considered to be of low, moderate and high study heterogeneity, respectively. The random-effects model (DerSimonian and Laird procedure) was applied to investigate the best therapeutic outcome among the selected studies. Results were deemed statistically significant if $p$-level $<0.05$. Data synthesis was performed using Stata version 17 (Stata Corp. LLC) software.

\section{Results}

A total of 461 articles were identified using the defined keywords, of which 13 clinical trials were included in the qualitative and quantitative analyses based on the outlined eligibility criteria with a total cohort of 1209 patients. The PRISMA flow chart is shown in Figure 3.
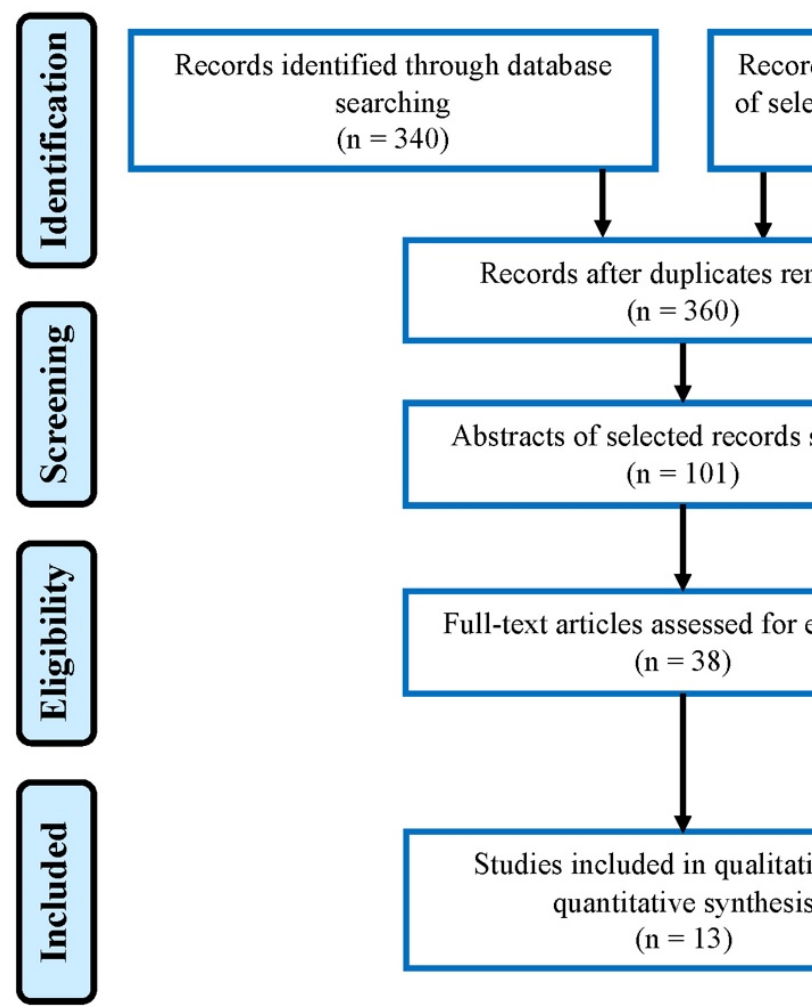

Records after duplicates removed

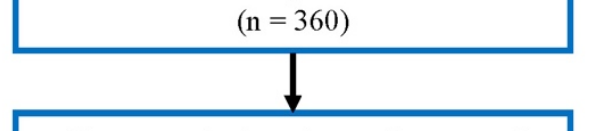

Abstracts of selected records screened

$$
(\mathrm{n}=101)
$$

Records excluded $(n=63)$

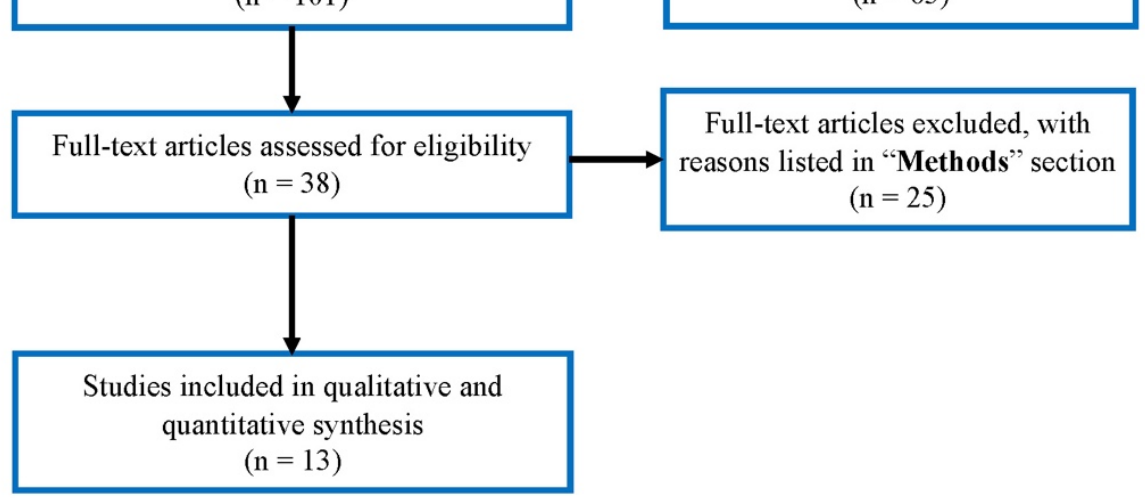

Figure 3. PRISMA flow chart of the systematic review.

\subsection{Checkpoint Blockade in Colorectal Cancer Patients with High Microsatellite Instability 3.1.1. Single PD-1 Inhibitor}

KEYNOTE-177 (NCT02563002), a randomized phase 3 clinical trial, investigated the efficacy of first-line pembrolizumab (PEMBRO $200 \mathrm{mg}$ Q3W) in patients with MSI$\mathrm{H} /$ deficient mismatch repair (dMMR) CRC compared to the standard of care (SoC) FOLFIRI (folinic acid, fluorouracil, irinotecan) or FOLFOX6 (folinic acid, fluorouracil, oxaliplatin), +/ - bevacizumab or cetuximab [19]. The median PFS reached 16.5 months in the PEMBRO- 
treated group $(n=153)$ compared to 8.2 months in the chemotherapy $(n=154)$ group (HR: $0.5(0.45-0.8), p=0.0002)$ [19]. PEMBRO-treated ORR reached $43.8 \%$ (95\% CI: 35.8 to 52 ), with $11.1 \%(n=17)$ and $32.7 \%(n=50)$ of the examined patients with complete $(\mathrm{CR})$ and partial responses (PR), respectively. In total, $67 \%(n=102)$ and $30 \%(n=42)$ had rightand left-side colon malignancy, respectively, and $75 \%(n=115)$ did not receive any prior therapy. The study concluded that PFS is consistently longer in patients treated with PEMBRO and resulted in the recent update of therapeutic guidelines for $\mathrm{mCRC}$ patients with MSI-H/dMMR [38].

A phase 2 single-arm trial, KEYNOTE-164 (NCT02460198), determined the efficacy of PEMBRO $200 \mathrm{mg}$ Q3W in mCRC patients with MSI-H status previously treated with $\geq 2$ (cohort $\mathrm{A}, n=61$ ) and $\geq 1$ (cohort $\mathrm{B}, n=63$ ) lines of systemic therapies [22]. The median PFS reached 2.3 months (95\% CI: 2.1 to 8.1 ) and 4.1 months (95\% CI: 2.1 to 18.9) in cohorts $A$ and B, respectively [22]. The ORR in both cohorts was 33\%, including 2 CRs and 18 PRs in cohort $\mathrm{A}$ and $5 \mathrm{CRs}$ and $16 \mathrm{PRs}$ in cohort $\mathrm{B}$ [22]. The data regarding tumor location were not reported. Finally, the authors concluded that PEMBRO provides durable clinical response in MSI-H/dMMR patients progressed on $\geq 2$ and $\geq 1$ lines of previous systemic treatment [22].

With regard to nivolumab (NIVO) monotherapy, the CheckMate142 (NCT02060188) phase 2 single-arm study established an ORR of 32\% (95\% CI: 22 to 44 ) with the median PFS of 14.3 months ( $95 \%$ CI: 4.3 to NR) [23]. Whereas $99 \%(n=73)$ of the patients had at least one line of prior chemotherapy, $100 \%$ of the patients were MSI-H/dMMR [23]. The authors concluded that NIVO $3 \mathrm{mg} / \mathrm{kg}$ Q2W reached a durable clinical response and survival rates and could be considered in further clinical trials; however, the primary tumor location was not reported [23].

\subsubsection{Single PD-L1 Inhibitor}

A phase $1 \mathrm{~b}$ trial (NCT01633970) investigated atezolizumab (ATEZO) + various chemotherapeutic/biological (bevacizumab) regimens in patients with advanced solid tumors [24] and recorded an ORR in mCRC patients of 30\% (95\% CI: 6.7 to 65.3), with the median PFS not reached by the time of data cutoff [24]. ATEZO $10 \mathrm{mg} / \mathrm{kg}$ Q3W was used in combination with bevacizumab $15 \mathrm{mg} / \mathrm{kg}$ Q3W among $n=10$ enrolled patients, of whom $n=7$ and $n=3$ had $\geq 2$ and 1 line(s) of previous chemotherapy, respectively [24]. Therapeutic efficacy was encouraging, and follow-up is ongoing, with the final results not yet reported.

A phase 2 single-arm study (NCT03150706) established that avelumab $10 \mathrm{mg} / \mathrm{kg}$ Q2W resulted in an ORR of $24.2 \%(12.1 \%(n=4)$ and $12.1 \%(n=4)$ achieved CR and PR, respectively) in MSI-H mCRC patients [29]. The median PFS reached 3.9 months (95\% CI: 2.3 to 5.6) [29]. The primary tumor was located in the right and left sides in $66.7 \%$ $(n=22)$ and $15.2 \%(n=5)$ of patients, respectively [29]. A total of $48.5 \%(n=16)$ and $51.5 \%(n=17)$ received $>1$ and $>2$ lines of previous chemotherapy, respectively. Overall, avelumab displayed a durable clinical response in MSI-H mCRC patients progressed on standard chemotherapy.

A phase 2 single-arm study (NCT01693562) investigating durvalumab (DURVA) in patients with advanced solid tumors demonstrated an ORR of 22\% (95\% CI: 10 to 39) and a median PFS of 6 months (95\% CI: 3 to 20) in $n=36$ mCRC patients [25]. DURVA $10 \mathrm{mg} / \mathrm{kg}$ Q2W showed promising antitumor activity in pre-treated mCRC patients, with the final results of this trial anticipated by Fall 2021. Finally, the examined studies showed that PD-L1 inhibitors can also provide a durable clinical response in $\mathrm{mCRC}$ patients with MSI-H status.

\subsubsection{Combination of CTLA-4 + PD-1 Inhibitors}

CheckMate142 (NCT02060188), a phase 2 single-arm study, demonstrated encouraging efficacy of NIVO $3 \mathrm{mg} / \mathrm{kg}$ in combination with ipilimumab (IPI) $1 \mathrm{mg} / \mathrm{kg}$ in MSI-H mCRC patients. ORR reached 54.6\% (95\% CI: 45.2 to 63.8) with median PFS not reached by the time of data cutoff [21]. Primary tumor location was in the right and left side in 55\% $(n=65)$ 
and $25 \%(n=30)$ of the patients, respectively [21]. The 12 -month PFS rate was $71 \%(95 \%$ CI:61.4 to 78.7) [21].

To summarize, the aforementioned trials validated ICIs as a therapeutic alternative for mCRC patients with MSI-H, particularly PEMBRO. NIVO as monotherapy or in combination with IPI has shown encouraging response rates and has also been approved by the FDA for mCRC patients progressed on standard chemotherapy. Finally, PD-L1 inhibitors have also shown encouraging response and survival rates; however, larger randomized trials are required (Figure 4).

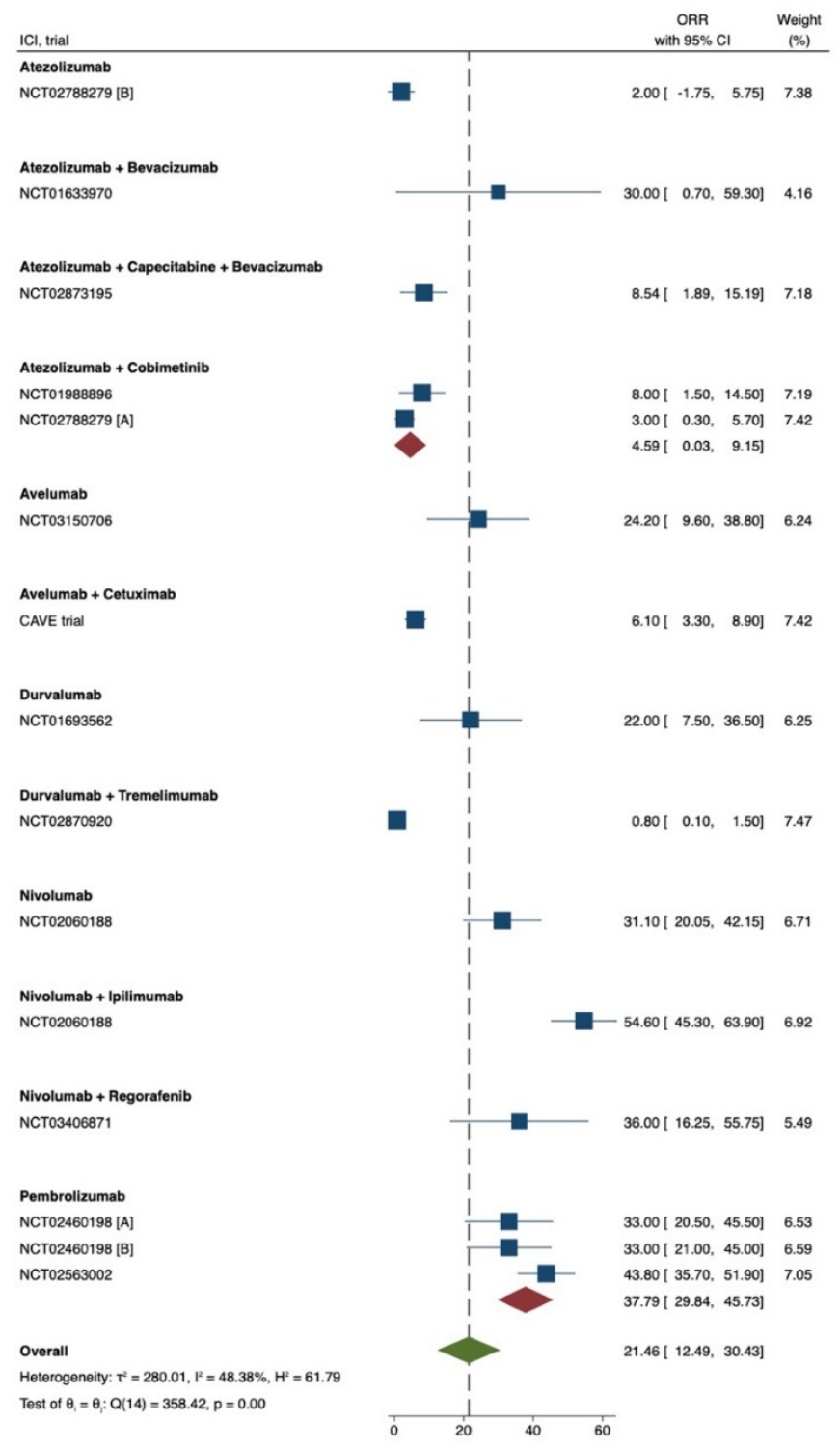

Figure 4. Forest plot visualizing the objective response rate across selected studies. The cumulative response rate is estimated to be $21.46 \%$ with non-significant differences in weight distribution across selected studies and study heterogeneity of $48.38 \%$ (deemed as moderate).

\subsection{Checkpoint Blockade in Colorectal Cancer Patients with Stable Microsatellite Status}

3.2.1. Immune-Checkpoint Inhibitors + Chemotherapeutic or Biological Agents

A phase 1b single-arm REGONIVO study (NCT03406871) investigated NIVO $3 \mathrm{mg} / \mathrm{kg}$ Q2W in combination with the multikinase inhibitor regorafenib $80-160 \mathrm{mg}$ in patients with advanced gastric cancer or CRC [27]. It demonstrated an ORR of 36\% (95\% CI: 18 to 57.5) with a median PFS of 7.9 months ( $95 \%$ CI: 2.0 to NR) in the mCRC cohort $(n=25)$ [27]. Of note, $96 \%(n=24)$ of the participants had MSS status with $20 \%(n=5)$ and $80 \%(n=20)$ 
had 2 and $\geq 3$ lines of prior chemotherapy, respectively [27]. In $80 \%(n=20)$ of the patients, the primary tumor was located in the left side or the rectum [27]. Overall, Fukuoka et al. reported encouraging antitumor activity in MSS mCRC patients, which are currently deemed ineligible for checkpoint blockade therapies. Further studies should be conducted to determine the outcomes of ICIs and kinase inhibitors in MSS patients.

A phase 3 randomized controlled trial, IMblaze 370 (NCT02788279), examined ATEZO $840 \mathrm{mg}$ Q2W + cobimetinib $60 \mathrm{mg}$ (cohort A) or ATEZO $1200 \mathrm{mg}$ Q3W (cohort B) compared to regorafenib $160 \mathrm{mg}$ in mCRC patients with MSS status [30]. The primary endpoint was not observed with no significant difference in overall survival compared to the control group treated with regorafenib [30]. A total of $93 \%(n=170)$ and $92 \%(n=83)$ of the patients in cohorts A and B, respectively, had MSS status [30]. Of note, the earlier trial (NCT01988896, phase 1b) also established a low clinical efficacy in MSS patients treated with ATEZO + cobimetinib [28]. These data have underscored the challenge of exploring ATEZO-based regimens in mCRC patients with MSS status.

A phase 2 randomized, placebo-controlled trial BACCI (NCT02873195) compared the outcomes between capecitabine + bevacizumab + placebo ( $\operatorname{arm~A,~} n=46)$ and capecitabine + bevacizumab + ATEZO (arm B, $n=82)$ in mCRC patients [26]. A total of $85.7 \%(n=70)$ of patients had MSS status [26]. No significant differences between study and control groups were established [26]. Nonetheless, study investigators have decided to conduct a phase 3 trial to further examine this regimen in mCRC patients with MSS status.

\subsubsection{Combination of CTLA-4 + PD-L1 Inhibitors}

A phase 2 randomized trial (NCT02870920) investigating DURVA + tremelimumab in mCRC patients with MSS status compared to the best supportive care (BSC) demonstrated no CR in the study group. In addition, only one patient (total cohort included $n=119$ ) achieved PR with the median PFS of 1.8 months [32]. No significant differences in PFS between the studied regimens were observed; however, stable disease (SD) was recorded in $22.7 \%(n=27)$ and $6.6 \%(n=4)$ of the patients treated with DURVA-based regimen and $\mathrm{BSC}$, respectively [32]. As the patients were of MSS status and had received at least one line of prior chemotherapy, the authors concluded that DURVA + tremelimumab may be of potential benefit for this patient population due to the lack of other treatment options [32].

To summarize, ICIs did not show encouraging clinical efficacy in mCRC patients with MSS status. The mechanisms underlying this resistance are currently unknown.

\subsection{Study Limitations}

Our study has limitations worth outlining. First, some of the selected studies did not define the number of therapeutic lines used prior to ICIs. Secondly, our analysis focused on determining efficacy clinical outcomes, disregarding safety outcomes in mCRC patients.

\section{Discussion}

Targeted therapy has opened a new chapter in the management of CRC, with ICIs providing a new hope for patients with advanced colonic malignancies [39]. In particular, the humanized anti-PD-1 mAb PEMBRO has recently become a new first-line therapeutic alternative for mCRC patients with MSI-H status [19]. The randomized KEYNOTE-177 trial reported significantly higher PFS and ORR among patients treated with PEMBRO compared to patients treated with SoC chemotherapy (mFOLFOX6 or FOLFIRI +/ - bevacizumab or cetuximab) [19]. PEMBRO has also shown high efficacy in pre-treated ( $>1$ and $>2$ lines of standard chemotherapy) mCRC patients with MSI-H status [22]. Another single PD-1 inhibitor, NIVO, has also shown durable clinical response in pre-treated mCRC patients with MSI-H status [23]. Similarly, PD-L1 inhibitors (ATEZO, Avelumab and DURVA) also demonstrated encouraging response rates in pre-treated MSI-H mCRC patients in early phases of clinical trials, with further studies ongoing [24,25,29]. These results emphasized the higher efficacy of single ICIs in mCRC patients with MSI-H status. In addition to these findings, the CheckMate142 trial reported that NIVO + IPI reached an impressive 
response rate in heavily pre-treated mCRC patients with MSI-H status ( $99 \%$ had $\geq 1$ lines of chemotherapy) [21]. Further investigation of doublet ICI therapy is currently ongoing.

By contrast, PD-1/PD-L1 inhibitors showed no clinical benefit in patients with MSS status $[26,28,30,32]$. The factors impacting lower response rates of ICI therapy in CRC patients with MSS status remain unknown. An analysis conducted by Mlecnik et al. [40] revealed that patients with MSI-H status possess a higher rate of mutations in ACVR2A (activin A receptor type 2A), FBXW7 (F-box and WD repeat domain-containing 7) and CTNNB1 (catenin beta 1) genes, and fewer mutations in APC (adenomatous polyposis coli), KRAS and TP53 (tumor protein 53) genes compared to patients with MSS status [41]. The underlying mechanisms to explain these differences are unknown. Other studies reported that MSI-H patients possessed higher tumor infiltration of CD3+, CD8+ and CD45RO+ T cells compared to their MSI-L counterparts [42,43]. Unfortunately, clinical trials using ICIs in patients with mCRC do not commonly conduct genome sequencing or phenotyping of tumor-infiltrating lymphocytes (TILs); thus, it is difficult to establish the impact of tumor mutational burden (TMB) or TILs across MSS patients within the selected clinical trials. The encouraging outcomes of REGONIVO trial (NIVO + regorafenib) [27] could perhaps be due to known activity of regorafenib to modulate the tumor immune microenvironment via polarization of antigen-presenting cells, particularly macrophages [44]. Ou et al. established that regorafenib is capable of inducing the p38MAPK/Creb1/Klf4 signaling pathway responsible for the activation of tumor-associated macrophages [44], and subsequent production of pro-inflammatory cytokines (IL-10, IL-12 and IL-23) responsible for activation of cytotoxic T cells [45]. Following on these insights, it is of particular interest to examine combinatorial regimens of ICIs with kinase inhibitors. Lastly, the expression of other checkpoint molecules (ICOS, TIM-3, LAG-3, GITR and OX40) and their role in T cell inhibition or activation in the context of CRC may explain the resistance to currently used PD-1/PD-L1 inhibitors [20]. Although the efficacy of novel checkpoint inhibitors is yet to be fully defined, there is hope that in the near future, the majority of CRC patients may be benefited from ICI-based therapies.

\section{Conclusion and Future Perspectives}

Our analysis suggests that PD-1 and PD-L1 inhibitors may have significant potency in mCRC patients with MSI-H/dMMR status. FDA approval has already been granted to some regimens for use as therapeutic alternatives in aforementioned patient populations. Nonetheless, further evaluation in larger phase 3 clinical trials is necessary and is ongoing (Table 2). Despite the promising efficacy of checkpoint blockade, it is commonly regarded as ineffective in patients with MSS status. Nonetheless, NIVO + regorafenib shows promise, though the trial was non-randomized and in a small cohort. Although clinical trials determining novel ICI-based combinatorial regimens in MSS patients are ongoing, it is also critical to conduct specifically designed translational studies to establish precise mechanisms of resistance in these patients. These studies may reveal previously unknown molecular patterns of CRC in patients with MSI-L and provide new strategies for overcoming therapeutic barriers. Understanding these roadblocks may, one day, result in successful and effective implementation of ICI therapy in a majority of patients with severely progressed or refractory colorectal cancer. 
Table 2. List of currently recruiting clinical trials determining clinical outcomes of PD-1/PD-L1/CTLA-4 inhibitors in patients with metastatic colorectal cancer. ICI—immune-checkpoint inhibitor; PEMBRO—pembrolizumab; NIVO—nivolumab; ATEZO—atezolizumab; IPI—ipilimumab; DURVA—durvalumab; ORR—objective response rate; PFS—progression-free survival; OS—overall survival; irAEs—immune-related adverse events; DCR—disease control rate; G—grade.

\begin{tabular}{|c|c|c|c|c|c|}
\hline NCT & Phase & Sponsor & ICI & Primary Endpoint & $\begin{array}{l}\text { Estimated Date for } \\
\text { Primary Results }\end{array}$ \\
\hline NCT04513951 & 2 & $\begin{array}{l}\text { Gruppo Oncologico del } \\
\text { Nord-Ovest }\end{array}$ & Avelumab & - $\quad$ PFS & May 2021 \\
\hline NCT04659382 & 2 & $\begin{array}{l}\text { Federation Francophone de } \\
\text { Cancerologie Digestive }\end{array}$ & ATEZO & - $\quad$ PFS & October 2021 \\
\hline NCT03983954 & 1 & NeoTX Therapeutics Ltd. & DURVA & $\begin{array}{ll}\text { - } & \text { Incidence of } \\
\text { irAEs } \\
\text { - } & \text { ORR }\end{array}$ & November 2021 \\
\hline NCT03475004 & 2 & $\begin{array}{l}\text { University of Colorado, } \\
\text { Denver }\end{array}$ & PEMBRO & - $\quad$ ORR & December 2021 \\
\hline NCT03388190 & 2 & University Hospital, Akershus & NIVO & - $\quad$ PFS & December 2021 \\
\hline NCT04575922 & 2 & $\begin{array}{c}\text { Massachusetts General } \\
\text { Hospital }\end{array}$ & NIVO + IPI & - $\quad$ ORR & December 2021 \\
\hline NCT03519412 & 2 & $\begin{array}{l}\text { IFOM, the FIRC Institute of } \\
\text { Molecular Oncology }\end{array}$ & PEMBRO & - $\quad$ ORR & February 2022 \\
\hline NCT03866239 & 1 & Hoffmann-La Roche & ATEZO & 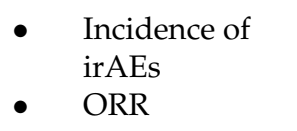 & February 2022 \\
\hline NCT02997228 & 3 & $\begin{array}{l}\text { National Cancer Institute } \\
\text { (NCI) }\end{array}$ & ATEZO & - $\quad$ PFS & April 2022 \\
\hline NCT03657641 & 2 & $\begin{array}{l}\text { University of Southern } \\
\text { California }\end{array}$ & PEMBRO & $\begin{array}{ll}\text { - } & \text { Dose-limiting } \\
& \text { toxicity } \\
\text { - } & \text { PFS } \\
\text { - } & \text { OS }\end{array}$ & June 2022 \\
\hline NCT04924179 & 2 & $\begin{array}{l}\text { Huazhong University of } \\
\text { Science and Technology }\end{array}$ & Tislelizumab & - $\quad$ PFS & December 2022 \\
\hline NCT03377361 & 2 & Bristol-Myers Squibb & NIVO & $\begin{array}{ll}\text { - } & \begin{array}{l}\text { Dose-limiting } \\
\text { toxicity }\end{array} \\
\text { - } & \text { Incidence of } \\
\text { irAEs } \\
\text { - } \\
\text { Incidence of } \\
\text { serious irAEs } \\
\text { - } \begin{array}{l}\text { Incidence of } \\
\text { deaths } \\
\text { - ORR }\end{array}\end{array}$ & January 2023 \\
\hline NCT04777162 & 2 & Peking University & Tislelizumab & - $\quad$ ORR & January 2023 \\
\hline NCT04730544 & 2 & $\begin{array}{l}\text { GERCOR-Multidisciplinary } \\
\text { Oncology Cooperative Group }\end{array}$ & NIVO + IPI & $\begin{array}{ll}\text { - } & \text { Number of } \\
\text { G.3-4 irAEs } \\
\text { - } & \text { PFS }\end{array}$ & March 2023 \\
\hline NCT03555149 & 2 & Hoffmann-La Roche & ATEZO & - $\quad$ ORR & April 2023 \\
\hline
\end{tabular}


Table 2. Cont.

\begin{tabular}{|c|c|c|c|c|c|}
\hline NCT & Phase & Sponsor & ICI & Primary Endpoint & $\begin{array}{l}\text { Estimated Date for } \\
\text { Primary Results }\end{array}$ \\
\hline NCT04262687 & 2 & $\begin{array}{l}\text { Federation Francophone de } \\
\text { Cancerologie Digestive }\end{array}$ & PEMBRO & - $\quad$ ORR & September 2023 \\
\hline NCT03374254 & 1 & Merck Sharp \& Dohme Corp. & PEMBRO & $\begin{array}{ll}\text { - } & \text { Dose-limiting } \\
\text { toxicity } \\
\text { - } & \text { ORR }\end{array}$ & November 2023 \\
\hline NCT04963283 & 2 & $\begin{array}{l}\text { University of Colorado, } \\
\text { Denver }\end{array}$ & NIVO & - $\quad$ DCR & February 2024 \\
\hline NCT03642067 & 2 & $\begin{array}{c}\text { Sidney Kimmel } \\
\text { Comprehensive Cancer } \\
\text { Center at Johns Hopkins }\end{array}$ & NIVO & - $\quad$ ORR & February 2024 \\
\hline NCT04776148 & 3 & Merck Sharp \& Dohme Corp. & PEMBRO & - $\quad$ OS & March 2024 \\
\hline NCT04017650 & 2 & M.D. Anderson Cancer Center & NIVO & $\begin{array}{ll}\text { - } & \text { ORR } \\
\text { - } & \text { Incidence of } \\
\text { G.3-4 irAEs }\end{array}$ & June 2024 \\
\hline NCT03396926 & 2 & $\begin{array}{l}\text { University of California, San } \\
\text { Francisco }\end{array}$ & PEMBRO & $\begin{array}{ll}\text { - } & \text { Dose-limiting } \\
\text { toxicity } \\
\text { - } & \text { ORR }\end{array}$ & January 2025 \\
\hline NCT04008030 & 3 & Bristol-Myers Squibb & $\begin{array}{l}\mathrm{NIVO} \text { or } \mathrm{NIVO}+ \\
\text { IPI }\end{array}$ & - $\quad$ PFS & August 2025 \\
\hline NCT04430985 & 2 & Dorte Nielsen & IPI & $\begin{array}{ll}\text { - Disease-free } \\
\text { survival }\end{array}$ & September 2025 \\
\hline
\end{tabular}

Author Contributions: All authors take responsibility for the integrity of the data and the accuracy of the data analysis. Conception/design: D.S. and G.A. Collection and/or assembly of data: D.S., L.A. and G.A. Data analysis and interpretation: D.S. and G.A. Manuscript writing: all authors. Final approval and critical revision of the manuscript: all authors. Supervision: B.G. and G.A. All authors have read and agreed to the published version of the manuscript.

Funding: This project was supported by the Ainsworth Bequest to the School of Medicine of Western Sydney University, the Robert W. Storr Bequest to the Sydney Medical Foundation of the University of Sydney and the Western Sydney Local Health District Research and Education Network Grant 2021.

Data Availability Statement: All data can be obtained from the corresponding author on a reasonable request via e-mail (Golo.Ahlenstiel@health.nsw.gov.au).

Conflicts of Interest: All authors declare that there are no competing interests that could have inappropriately influenced results of this study.

\section{References}

1. Bray, F.; Ferlay, J.; Soerjomataram, I.; Siegel, R.L.; Torre, L.A.; Jemal, A. Global cancer statistics 2018: GLOBOCAN estimates of incidence and mortality worldwide for 36 cancers in 185 countries. CA Cancer J. Clin. 2018, 68, 394-424. [CrossRef]

2. Dekker, E.; Tanis, P.J.; Vleugels, J.L.A.; Kasi, P.M.; Wallace, M.B. Colorectal cancer. Lancet 2019, 394, 1467-1480. [CrossRef]

3. Siegel, R.L.; Miller, K.D.; Jemal, A. Cancer statistics, 2019. CA Cancer J. Clin. 2019, 69, 7-34. [CrossRef]

4. Siegel, R.L.; Miller, K.D.; Goding Sauer, A.; Fedewa, S.A.; Butterly, L.F.; Anderson, J.C.; Cercek, A.; Smith, R.A.; Jemal, A. Colorectal cancer statistics, 2020. CA Cancer J. Clin. 2020, 70, 145-164. [CrossRef]

5. Wolf, A.M.D.; Fontham, E.T.H.; Church, T.R.; Flowers, C.R.; Guerra, C.E.; LaMonte, S.J.; Etzioni, R.; McKenna, M.T.; Oeffinger, K.C.; Shih, Y.T.; et al. Colorectal cancer screening for average-risk adults: 2018 guideline update from the American Cancer Society. CA Cancer J. Clin. 2018, 68, 250-281. [CrossRef] 
6. Van der Stok, E.P.; Spaander, M.C.W.; Grunhagen, D.J.; Verhoef, C.; Kuipers, E.J. Surveillance after curative treatment for colorectal cancer. Nat. Rev. Clin. Oncol. 2017, 14, 297-315. [CrossRef]

7. Messersmith, W.A. NCCN guidelines updates: Management of metastatic colorectal cancer. J. Natl. Compr. Cancer Netw. 2019, 17, 599-601.

8. Amin, M.B.; Greene, F.L.; Edge, S.B.; Compton, C.C.; Gershenwald, J.E.; Brookland, R.K.; Meyer, L.; Gress, D.M.; Byrd, D.R.; Winchester, D.P. The eighth edition AJCC cancer staging manual: Continuing to build a bridge from a population-based to a more "personalized" approach to cancer staging. CA Cancer J. Clin. 2017, 67, 93-99. [CrossRef]

9. Lee, Y.T.; Tan, Y.J.; Oon, C.E. Molecular targeted therapy: Treating cancer with specificity. Eur. J. Pharmacol. 2018, 834, 188-196. [CrossRef]

10. Yarom, N.; Jonker, D.J. The role of the epidermal growth factor receptor in the mechanism and treatment of colorectal cancer. Discov. Med. 2011, 11, 95-105.

11. Vecchione, L.; Jacobs, B.; Normanno, N.; Ciardiello, F.; Tejpar, S. EGFR-targeted therapy. Exp. Cell Res. 2011, 317, $2765-2771$. [CrossRef]

12. Mizukami, T.; Izawa, N.; Nakajima, T.E.; Sunakawa, Y. Targeting EGFR and RAS/RAF signaling in the treatment of metastatic colorectal cancer: From current treatment strategies to future perspectives. Drugs 2019, 79, 633-645. [CrossRef]

13. Ferrara, N.; Gerber, H.P.; LeCouter, J. The biology of VEGF and its receptors. Nat. Med. 2003, 9, 669-676. [CrossRef]

14. Folkman, J. Tumor angiogenesis: Therapeutic implications. N. Engl. J. Med. 1971, 285, 1182-1186. [PubMed]

15. Goel, H.L.; Mercurio, A.M. VEGF targets the tumour cell. Nat. Rev. Cancer 2013, 13, 871-882. [CrossRef] [PubMed]

16. Lopez, A.; Harada, K.; Vasilakopoulou, M.; Shanbhag, N.; Ajani, J.A. Targeting angiogenesis in colorectal carcinoma. Drugs 2019, 79, 63-74. [CrossRef] [PubMed]

17. Ganesh, K.; Stadler, Z.K.; Cercek, A.; Mendelsohn, R.B.; Shia, J.; Segal, N.H.; Diaz, L.A., Jr. Immunotherapy in colorectal cancer: Rationale, challenges and potential. Nat. Rev. Gastroenterol. Hepatol. 2019, 16, 361-375. [CrossRef] [PubMed]

18. Shek, D.; Read, S.A.; Nagrial, A.; Carlino, M.S.; Gao, B.; George, J.; Ahlenstiel, G. Immune-checkpoint inhibitors for advanced hepatocellular carcinoma: A synopsis of response rates. Oncologist 2021, 26, e1216-e1225. [CrossRef] [PubMed]

19. Andre, T.; Shiu, K.K.; Kim, T.W.; Jensen, B.V.; Jensen, L.H.; Punt, C.; Smith, D.; Garcia-Carbonero, R.; Benavides, M.; Gibbs, P.; et al. Pembrolizumab in microsatellite-instability-high advanced colorectal cancer. N. Engl. J. Med. 2020, 383, 2207-2218. [CrossRef]

20. Overman, M.J.; Ernstoff, M.S.; Morse, M.A. Where we stand with immunotherapy in colorectal cancer: Deficient mismatch repair, proficient mismatch repair, and toxicity management. Am. Soc. Clin. Oncol. Educ. Book 2018, 38, 239-247. [CrossRef]

21. Overman, M.J.; Lonardi, S.; Wong, K.Y.M.; Lenz, H.J.; Gelsomino, F.; Aglietta, M.; Morse, M.A.; Van Cutsem, E.; McDermott, R.; Hill, A.; et al. Durable clinical benefit with nivolumab plus ipilimumab in DNA mismatch repair-deficient/microsatellite instability-high metastatic colorectal cancer. J. Clin. Oncol. 2018, 36, 773-779. [CrossRef]

22. Le, D.T.; Kim, T.W.; Van Cutsem, E.; Geva, R.; Jager, D.; Hara, H.; Burge, M.; O’Neil, B.; Kavan, P.; Yoshino, T.; et al. Phase II open-label study of pembrolizumab in treatment-refractory, microsatellite instability-high/mismatch repair-deficient metastatic colorectal cancer: KEYNOTE-164. J. Clin. Oncol. 2020, 38, 11-19. [CrossRef]

23. Overman, M.J.; McDermott, R.; Leach, J.L.; Lonardi, S.; Lenz, H.J.; Morse, M.A.; Desai, J.; Hill, A.; Axelson, M.; Moss, R.A.; et al. Nivolumab in patients with metastatic DNA mismatch repair-deficient or microsatellite instability-high colorectal cancer (CheckMate 142): An open-label, multicentre, phase 2 study. Lancet Oncol. 2017, 18, 1182-1191. [CrossRef]

24. Hochster, H.S.; Bendell, J.C.; Cleary, J.M.; Foster, P.; Zhang, W.; He, X.; Hernandez, G.; Iizuka, K.; Eckhardt, S.G. Efficacy and safety of atezolizumab (atezo) and bevacizumab (bev) in a phase Ib study of microsatellite instability (MSI)-high metastatic colorectal cancer (mCRC). J. Clin. Oncol. 2017, 35, 673. [CrossRef]

25. Segal, N.H.; Wainberg, Z.A.; Overman, M.J.; Ascierto, P.A.; Arkenau, H.-T.; Butler, M.O.; Eder, J.P.; Keilholz, U.; Kim, D.-W.; Cunningham, D.; et al. Safety and clinical activity of durvalumab monotherapy in patients with microsatellite instability-high (MSI-H) tumors. J. Clin. Oncol. 2019, 37, 670. [CrossRef]

26. Mettu, N.B.; Twohy, E.; Ou, F.S.; Halfdanarson, T.R.; Lenz, H.J.; Breakstone, R.; Boland, P.M.; Crysler, O.; Wu, C.; Grothey, A.; et al. BACCI: A phase II randomized, double-blind, multicenter, placebo-controlled study of capecitabine (C) bevacizumab (B) plus atezolizumab (A) or placebo $(\mathrm{P})$ in refractory metastatic colorectal cancer (mCRC): An ACCRU network study. Ann. Oncol. 2019, 30, v203. [CrossRef]

27. Fukuoka, S.; Hara, H.; Takahashi, N.; Kojima, T.; Kawazoe, A.; Asayama, M.; Yoshii, T.; Kotani, D.; Tamura, H.; Mikamoto, Y.; et al. Regorafenib plus nivolumab in patients with advanced gastric or colorectal cancer: An open-label, dose-escalation, and dose-expansion phase Ib trial (REGONIVO, EPOC1603). J. Clin. Oncol. 2020, 38, 2053-2061. [CrossRef]

28. Hellmann, M.D.; Kim, T.W.; Lee, C.B.; Goh, B.C.; Miller, W.H., Jr.; Oh, D.Y.; Jamal, R.; Chee, C.E.; Chow, L.Q.M.; Gainor, J.F.; et al. Phase Ib study of atezolizumab combined with cobimetinib in patients with solid tumors. Ann. Oncol. 2019, 30, 1134-1142. [CrossRef]

29. Kim, J.H.; Kim, S.Y.; Baek, J.Y.; Cha, Y.J.; Ahn, J.B.; Kim, H.S.; Lee, K.W.; Kim, J.W.; Kim, T.Y.; Chang, W.J.; et al. A phase II study of avelumab monotherapy in patients with mismatch repair-deficient/microsatellite instability-high or POLE-mutated metastatic or unresectable colorectal cancer. Cancer Res. Treat. 2020, 52, 1135-1144. [CrossRef]

30. Eng, C.; Kim, T.W.; Bendell, J.; Argiles, G.; Tebbutt, N.C.; Di Bartolomeo, M.; Falcone, A.; Fakih, M.; Kozloff, M.; Segal, N.H.; et al. Atezolizumab with or without cobimetinib versus regorafenib in previously treated metastatic colorectal cancer (IMblaze370): A multicentre, open-label, phase 3, randomised, controlled trial. Lancet Oncol. 2019, 20, 849-861. [CrossRef] 
31. Martinelli, E.; Martini, G.; Troiani, T.; Pietrantonio, F.; Avallone, A.; Normanno, N.; Nappi, A.; Maiello, E.; Falcone, A.; Santabarbara, G.; et al. 397O Avelumab plus cetuximab in pre-treated RAS wild type metastatic colorectal cancer patients as a rechallenge strategy: The phase II CAVE (cetuximab-avelumab) mCRC study. Ann. Oncol. 2020, 31, S409-S410. [CrossRef]

32. Chen, E.X.; Jonker, D.J.; Loree, J.M.; Kennecke, H.F.; Berry, S.R.; Couture, F.; Ahmad, C.E.; Goffin, J.R.; Kavan, P.; Harb, M.; et al. Effect of combined immune checkpoint inhibition vs best supportive care alone in patients with advanced colorectal cancer: The Canadian cancer trials group CO.26 study. JAMA Oncol. 2020, 6, 831-838. [CrossRef] [PubMed]

33. Moher, D.; Liberati, A.; Tetzlaff, J.; Altman, D.G.; Group, P. Preferred reporting items for systematic reviews and meta-analyses: The PRISMA statement. PLoS Med. 2009, 6, e1000097. [CrossRef] [PubMed]

34. Higgins, J.P.; Altman, D.G.; Gotzsche, P.C.; Juni, P.; Moher, D.; Oxman, A.D.; Savovic, J.; Schulz, K.F.; Weeks, L.; Sterne, J.A.; et al. The cochrane collaboration's tool for assessing risk of bias in randomised trials. BMJ 2011, 343, d5928. [CrossRef] [PubMed]

35. Sterne, J.A.C.; Savovic, J.; Page, M.J.; Elbers, R.G.; Blencowe, N.S.; Boutron, I.; Cates, C.J.; Cheng, H.Y.; Corbett, M.S.; Eldridge, S.M.; et al. RoB 2: A revised tool for assessing risk of bias in randomised trials. BMJ 2019, 366, 14898. [CrossRef]

36. Wells, G.S.B.; O'Connell, D.; Peterson, J.; Welch, V.; Losos, M.; Tugwell, P. The Newcastle-Ottawa Scale (NOS) for Assessing the Quality of Nonrandomised Studies in Meta-Analyses. Available online: http:/ / wwwohrica/programs/clinical_epidemiology/ oxfordasp2013 (accessed on 22 June 2021).

37. Korn, R.L.; Crowley, J.J. Overview: Progression-free survival as an endpoint in clinical trials with solid tumors. Clin. Cancer Res. 2013, 19, 2607-2612. [CrossRef]

38. U.S. Food \& Drug Administration. FDA Approves Pembrolizumab for First-Line Treatment of MSI-H/dMMR Colorectal Cancer. Available online: https:/ / wwwfdagov/drugs/drug-approvals-and-databases/fda-approves-pembrolizumab-first-linetreatment-msi-hdmmr-colorectal-cancer (accessed on 12 July 2021).

39. Xie, Y.H.; Chen, Y.X.; Fang, J.Y. Comprehensive review of targeted therapy for colorectal cancer. Signal. Transduct. Target. Ther. 2020, 5, 22. [CrossRef]

40. Mlecnik, B.; Bindea, G.; Angell, H.K.; Maby, P.; Angelova, M.; Tougeron, D.; Church, S.E.; Lafontaine, L.; Fischer, M.; Fredriksen, T.; et al. Integrative analyses of colorectal cancer show immunoscore is a stronger predictor of patient survival than microsatellite instability. Immunity 2016, 44, 698-711. [CrossRef]

41. Westra, J.L.; Plukker, J.T.; Buys, C.H.; Hofstra, R.M. Genetic alterations in locally advanced stage II/III colon cancer: A search for prognostic markers. Clin. Colorectal. Cancer 2004, 4, 252-259. [CrossRef]

42. Nosho, K.; Baba, Y.; Tanaka, N.; Shima, K.; Hayashi, M.; Meyerhardt, J.A.; Giovannucci, E.; Dranoff, G.; Fuchs, C.S.; Ogino, S. Tumour-infiltrating T-cell subsets, molecular changes in colorectal cancer, and prognosis: Cohort study and literature review. J. Pathol. 2010, 222, 350-366. [CrossRef]

43. Rooney, M.S.; Shukla, S.A.; Wu, C.J.; Getz, G.; Hacohen, N. Molecular and genetic properties of tumors associated with local immune cytolytic activity. Cell 2015, 160, 48-61. [CrossRef] [PubMed]

44. Ou, D.L.; Chen, C.W.; Hsu, C.L.; Chung, C.H.; Feng, Z.R.; Lee, B.S.; Cheng, A.L.; Yang, M.H.; Hsu, C. Regorafenib enhances antitumor immunity via inhibition of p38 kinase/Creb1/Klf4 axis in tumor-associated macrophages. J. Immunother. Cancer 2021, 9, e001657. [CrossRef] [PubMed]

45. Lin, Y.; Xu, J.; Lan, H. Tumor-associated macrophages in tumor metastasis: Biological roles and clinical therapeutic applications. J. Hematol. Oncol. 2019, 12, 76. [CrossRef] [PubMed] 